\title{
Effect of Origanum Oil and Vinegar on the Maintenance of Postharvest Quality of Tomato
}

\author{
Nikos G. Tzortzakis ${ }^{1,2}$, Katerina Tzanakaki ${ }^{2}$, Costas D. Economakis ${ }^{1}$ \\ ${ }^{1}$ Department of Hydroponics and Aromatic Plants, Institute of Olive Tree and Subtropical Plants, National Agriculture Research \\ Foundation of Greece, Chania, Greece; ${ }^{2}$ Department of Organic Greenhouse Crops and Floriculture, School of Agricultural Tech- \\ nology, Technological Educational Institute of Crete, Heraklion, Greece. \\ Email: ntzortzakis@staff.teicrete.gr
}

Received September $1^{\text {st }}, 2011$; revised September $30^{\text {th }}, 2011$; accepted October $15^{\text {th }}, 2011$.

\begin{abstract}
Tomato fruits (Solanum lycopersicum, L.) were exposed to origanum oil, vinegar, or chlorine at $12{ }^{\circ} \mathrm{C}$ and $95 \% \mathrm{RH}$. Quality-related attributes were examined during or following vapour treatment. Fruit pre-treated with natural volatiles and transferred to ambient air had less decay compared to control fruits. Vinegar-enrichment maintained fruit firmness and acidity during exposure, though the effect was sustained only for acidity following storage in ambient air. Glucose and fructose levels were higher in origanum oil-treated fruit, while ascorbic acid content increased in volatile-treated fruits following transfer/storage in ambient air. Total phenolics declined during vinegar and chlorine exposure but tended to increase following transfer to ambient air. Vinegar and chlorine increased lycopene concentration during exposure to vapours, and this effect persisted only for vinegar following exposure and transfer in ambient air. Origanum oil-treated fruit increased lycopene concentration following exposure and transfer in ambient air. Vapourtreatment did not affect fruit weight and ethylene production. Natural volatiles may maintain fruit quality in addition to the well documented antimicrobial protection during fresh produce storage and transit.
\end{abstract}

Keywords: Fruit Storage, Natural Products, Preservation, Quality-Related Attributes, Tomato, Volatiles

\section{Introduction}

Due to the economical impacts of spoiled foods and the consumer's concerns over the safety of foods containing synthetic chemicals, a lot of attention has been paid to naturally derived compounds or natural products [1]. Recently, there has been considerable interest in extracts and essential oils from aromatic plants with antimicrobial activities for controlling pathogens and/or toxin producing microorganisms in foods which are considered as human-safe and environmentally friendly [1-3]. Most of the natural products are readily available, environmentally safe, with low risk for developing resistance to pests, less hazardous to non target organisms and pest resurgence, less adverse effect on plant growth, less harmful to seed viability and quality, and above all, occasionally less expensive than some of the chemical treatments [4]. Thus natural plant products are catching the attention of scientists worldwide.

Natural volatile compounds, including vinegar and essential oil have been extensively investigated and demonstrated to elicit as antibacterial and antifungal activities
$[5,6]$. Acetic acid or vinegar vapour was effective in preventing conidia of brown rot (Monilinia fructicola), grey mould (Botrytis cinerea) and blue mould (Penicillium italicum) from germinating and causing decay of stone fruits, strawberries and apples [5]. Acetic acid vapour also reduced postharvest brown rot of apricot and plums [7]. However, the low acetic acid content, that makes vinegar safe, also limits its effectiveness. As a conesquence, further studies may be needed to improve vinegar efficient.

The bioactivity of essential oils in the vapour phase is of great advantage and consist a characteristic that makes them useful as possible fumigants for stored fresh produce preservation [8]. Several studies, including origanum oils, reported the effectiveness of essential oil for fresh produce preservation such as sweet cherry, banana, kiwi, grape, pear, avocado, strawberry and tomato [8-13]. Such new treatments could have relatively high acceptance because of consumer's preference for natural plant products, e.g. essential oils compared with synthetic fungicides [12]. 
Many aspects encompass fruit quality, and include not only firmness, flavour, colour, and nutritional value, but also shelf life, processing attributes and resistance to pathogens [14]. The effect of natural volatiles on fresh produce preservation was investigated on only a few commodities (i.e. papaya [15]; pear [11]; kiwifruit [16]; tomato and strawberry [13]. Moreover, previous work has shown that ethanol and acetaldehyde can retard ripening in some fruit, such as tomatoes [17-19], while it can stimulate ripening in others, such as kiwifruit [20]. The present study was undertaken to determine if origanum oil as well as vinegar vapours would reduce decay and maintain better quality and shelf life of tomato fruit.

\section{Materials and Methods}

\subsection{Plant Materials}

Tomato fruit (Solanum lycopersicum L. cv Carousel) were obtained from local field (crop cultivated under commercial conditions and standard cultural practices in a clay loam soil, frequently irrigated according to crop needs), Chania, Greece. Fruit, following harvest, were randomised in uniform size, colour, ripeness (red-ripe stage) and free from defect or injury and then used for experimental needs. Organic essential oils derived from origanum [Origanum vulgare L. (Lamiaceae)], harvested in hilly area of Crete (without any man inputs); were extracted by hydrodistillation (Clevenger apparatus for 3 h). The analysis of the essential oil was performed using a Hewlett Packard 6890 GC, equipped with a HP-5MS (Crosslinked 5\% PH ME Siloxane) capillary column (30 $\mathrm{m}, 0.25 \mathrm{~mm}$ i.d., $0.25 \mathrm{~mm}$ film thickness) and a mass spectrometer 5973 as detector. The carrier gas was helium, by a rate of $1 \mathrm{~mL} / \mathrm{min}$. Column temperature was initially kept for $3 \mathrm{~min}$ at $50^{\circ} \mathrm{C}$, then gradually increased to $300^{\circ} \mathrm{C}$ at a $4^{\circ} \mathrm{C} \mathrm{min}^{-1}$ rate and then held to $300^{\circ} \mathrm{C}$ for $20 \mathrm{~min}$. For GC-MS detection an electron ionization system was used with ionization energy of $70 \mathrm{eV}$. Injector and detector (MS transfer line) temperatures were set at $230^{\circ} \mathrm{C}$ and $310^{\circ} \mathrm{C}$, respectively. Diluted samples of 0.1 $\mathrm{mL}$ were injected manually and splitless. The relative percentage-concentration of compounds was obtained by integrating the peak area of the chromatograms (see Table 1) and carvacrol was the predominant component.

\subsection{Treatments with Natural Volatiles}

Full-ripe tomato fruits for each individual treatment were placed into $1.9 \mathrm{~L}$ polystyrene containers with snap-on lids. Volatile compounds used in this study (concentrations related to previous studies) included vinegar (VIN; commercial product $(\sim 5 \%$ acetic acid); $16 \mathrm{~mL} / \mathrm{L})$, chlorine $(\mathrm{CHL} ; 48 \mathrm{~mL} / \mathrm{L}$ of $5 \% \mathrm{NaOCl})$ or origanum essential oil (ORI; $0.4 \mathrm{~mL} / \mathrm{L})$ diluted in $\mathrm{dH}_{2} \mathrm{O}$. Aliquot $(30 \mathrm{~mL})$ of
Table 1. Percentage composition $(>1 \%)$ of the essential oils from origanum isolated by GC/MS.

\begin{tabular}{ccc}
\hline Components & Retention Time $(\mathrm{min})$ & \% of total area \\
\hline$\alpha$-Terpinolene & 15.300 & 1.081 \\
$p$-Cymene & 15.633 & 7.318 \\
$\gamma$-Terpinene & 17.053 & 5.303 \\
cis-.beta.-Terpineol & 17.475 & 1.084 \\
Carvacrol & 26.228 & 83.545 \\
Caryophyllene & 30.011 & 1.199 \\
\hline
\end{tabular}

each volatile-solution was placed into individual small beakers, which were subsequently placed inside the plastic containers just before the lids were covered. Filter paper moistened with water placed into each container, maintaining high relative humidity ( $\mathrm{RH} \sim 95 \%)$ during the storage period. The volatile compounds were allowed to vaporize inside the containers spontaneously at $20^{\circ} \mathrm{C}$ for $7-8 \mathrm{~h}$. The containers were then transferred to storage at $12^{\circ} \mathrm{C}$ in a cold room. Tomato fruit exposed to control (ambient air; $20^{\circ} \mathrm{C}-24^{\circ} \mathrm{C}$ ) or volatiles for one week at $12^{\circ} \mathrm{C}$. Following 1 week exposure, a second batch of fruits were transferred to ambient air and stored at $12^{\circ} \mathrm{C}$ for an additional one week. Containers were aerated every $72 \mathrm{~h}$ avoiding air concentration abnormalities. All experiments were repeated twice and vapour treatment conducted in five replicates batches (on a minimum of six independent replicate fruit per batch) exposed in volatile compounds each time point for every treatment. No phytotoxic effect on tomato fruit observed following volatiles exposure.

\subsection{Decay Evaluation}

The severity of fruit (in individual fruit in each container; total 30 fruits per treatment) decay was visually evaluated during and following exposure to volatiles compounds. The degree of infection on fruit was rated using a scale of 1 to 5, where 1-clean, no infection, 2-trace infection, 3-slight infection, 4-moderate infection, and 5severe infection.

\subsection{Water Loss, Fruit Firmness and Ethylene Production of Tomato Fruit}

Healthy (no-infected) fruits were labelled and the weight recorded prior to exposure to ambient air or volatile-enriched air (VIN, CHL or ORI). Fruits were weighed after one or two weeks intervals and percent weight loss of original weight was computed. Fruit firmness was measured at 2 points on the shoulder of tomato fruit (skin removed), respectively for each treatment by applying a 
plunger of $8 \mathrm{~mm}$ in diameter, using a texturometer FT 011 (TR Scientific Instruments, Forli, Italy). The amount of force (in Newtons; N) required to break the radial pericarp (i.e. surface) of each tomato was recorded at ambient $\left(22^{\circ} \mathrm{C}-24^{\circ} \mathrm{C}\right)$ temperature.

Ethylene production by tomato fruit ( 6 individual fruits) was estimated as described in previous studies [21]. In details, following exposure of fruit to vapours, fruit was weighed and measured, then placed in airtight glass jars $(1.2 \mathrm{~L}$ ) for $10 \mathrm{~min}$ (to allow equilibrium at room temperature). After $10 \mathrm{~min}$ equilibration, the flask was sealed. Head-space samples for ethylene determination were taken after $1 \mathrm{~h}$ incubation in the dark at room temperature. Air samples were introduced into a gas chromatograph equipped with a flame ionisation detector (Shimadzu GC-14B, Kyoto, Japan), AT-1701 capillary columns (Alltech Heliflex, Illinois, USA; $15 \mu \mathrm{m}$, ID 0.53 $\mathrm{mm})$. The column was operated isothermally at $70^{\circ} \mathrm{C}$. The following conditions were used for operating the GC: sample size, $0.5 \mathrm{~mL}$; carrier gas $(\mathrm{He}), 100 \mathrm{kPa} ; \mathrm{H}_{2}, 60$ $\mathrm{kPa}$; air, $50 \mathrm{kPa}$; detector temperature at $200^{\circ} \mathrm{C}$; injector temperature at $180^{\circ} \mathrm{C}$; running time for $5 \mathrm{~min}$. All measurements were duplicated, flow rates recorded and ethylene emission $(\mu \mathrm{L} / \mathrm{Kg} / \mathrm{h})$ was computed (employing a $10 \mu \mathrm{mol} / \mathrm{mol}$ ethylene external standard).

\subsection{Soluble Sugar, Organic Acid, Ascorbic Acid (Vitamin C) and Phenolic Content of Tomato fruit}

Soluble sugars were extracted from six independent tomato fruit (c. $0.5 \mathrm{~g})$ in $80 \%(\mathrm{v} / \mathrm{v})$ methanol. Extracts were passed through ion exchange columns (Dowex AG50W and Amberlite IRA-67 in series, Sigma Aldrich, Athens, Greece) and analysed via high-performance liquid chromatography (HPLC) as reported previously [19]. Titratable acidity (TA) was determined by potentiometric titration, using six independent fruit samples $(5 \mathrm{~g}$ blended tissue) diluted in $100 \mathrm{~mL}$ distilled water and titrated with $0.1 \mathrm{~N} \mathrm{NaOH}$ with the formation of a pink precipitate and monitored using phenolphthalein as $\mathrm{pH}$ indicator. The reported values were expressed in terms of citric acid percentage. Total phenolic concentration was determined from blended fruit (6 individual fruits) tissue extracts (5 g) of following repeated (4-fold) addition of $2.5 \mathrm{~mL}$ of $50 \%(\mathrm{v} / \mathrm{v})$ methanol under ultrasonication. Aliquots were collected and centrifuged for $5 \mathrm{~min}$ at $4^{\circ} \mathrm{C}$ at $3000 \mathrm{~g}$. The supernatant was transferred to a fresh Eppendorf tube and $125 \mu \mathrm{L}$ pipetted into a fresh test tube, to which 1.5 $\mathrm{mL}$ of water (Milli-Q), $125 \mu \mathrm{L}$ of Folin-Ciocalteu's reagent (Sigma Aldrich, Athens, Greece) and $1.25 \mathrm{~mL}$ of $7 \%(\mathrm{w} / \mathrm{v})$ sodium carbonate were added. The reaction mix $(3 \mathrm{~mL})$ was incubated in the dark for $1.5 \mathrm{~h}$, prior to reading the absorbance at $755 \mathrm{~nm}$ (Genesys 10 Vis, Ther-
moSpectronic, Rochester, USA). Results were expressed in terms of gallic acid equivalents (GAE; Sigma Aldrich, Athens, Greece). Ascorbic acid (consisting the major part in Vitamin C) in six independent tomato juice was determined by the 2,6-Dichloroindophenol titrimetric method [22].

\subsection{Carotenoids Composition in Tomato Fruit}

Carotenoids (lycopene, lutein and $\beta$-carotene) composition in tomato fruit ( 3 cumulative samples from 6 tomatoes per batch) was determined from homogenised tomato tissue $(c .5 \mathrm{~g})$ which was added to a round-bottomed flask with $4 \mathrm{~g}$ silica gel and subjected to rotary evaporation under vacuum at a maximum of $35^{\circ} \mathrm{C}$. Methanol $(10 \mathrm{~mL})$ was added to capture remaining water and assist in the transfer of lipophilic carotenoids, prior to ultrasonication and evaporation under vacuum. Volumes of $10 \mathrm{~mL}$ tetrahydrofuran and $10 \mathrm{~mL}$ of acetone were added, and the solution subjected to ultrasonication. This procedure was repeated three times, until a colourless tomato tissue was obtained. The extracts were bulked together in a conical flask, and then subjected to evaporation under vacuum prior to re-suspension in $c .40$ $\mathrm{mL}$ ethyl acetate and $\mathrm{dH}_{2} \mathrm{O}$. The organic phase (coloured layer) was collected by employing a separation funnel and dried using anhydrous $\mathrm{Na}_{2} \mathrm{SO}_{4}$, prior to evaporating the solvent under vacuum in a fresh flask. The residue was re-extracted in $10 \mathrm{~mL}$ ethyl acetate, and stored at $-20^{\circ} \mathrm{C}$ prior to analysis. Standard precautions were taken throughout to prevent exposure of carotenoids to light, oxygen, acid and heat. Carotenoids were determined by means of HPLC analysis on a RP18 Lichrospher 100 (Merck, Darmstadt, Germany) $250 \times 4(5 \mu)$ column and DAD detection at $455 \mathrm{~nm}$. Eluent (A) was acetonitrile: water $(9: 1 \mathrm{v} / \mathrm{v})$ containing $0.1 \%$ triethylamine and (B) ethyl acetate and the mobile phase were $1 \mathrm{~mL} / \mathrm{min}$. The elution programme used followed by a linear gradient as follows: from $100 \% \mathrm{~A}$ to $0 \% \mathrm{~A}$ in $25 \mathrm{~min}$ (total run time $35 \mathrm{~min}$ ). Conditions were returned to $100 \%$ solution A by linear gradient within $3 \mathrm{~min}$, and held on the washing step for $7 \mathrm{~min}$. The temperature of the column was kept at $40^{\circ} \mathrm{C}$. Quantification was performed by using external calibration curves and was prepared in the range $0-186$ $\mathrm{nmol} / \mathrm{mL} \beta$-carotene, lutein and lycopene employing HPLC gradient standards (Sigma Aldrich, Athens, Greece).

\subsection{Statistical Analysis}

Data were first tested for normality, and then subjected to analysis of variance (ANOVA). Sources of variation were time of storage and treatments. Significant differrences between mean values were determined using the LSD $(P=0.05)$. Significant differences on percentage 
values (weight loss) were logarithmic transformed prior to using ANOVA. Statistical analyses were performed using SPSS (SPSS Inc., Chicago, USA) and graphs were produced using Prism v.2.0 (Graph Pad Inc., San Diego, USA).

\section{Results and Discussions}

\subsection{Effect of Volatiles Vapour on Fruit Decay}

Vapour-treated fruit had a lower severity of decay [mainly anthracnose rot (caused by Colletotrichum coccodes) and secondary black spot (caused by Alternaria alternata)] following vapour exposure and transference to ambient air, with oregano as the best treatment (up to $59 \%$ decay reduction compare with the control), followed by chlorine treatment. Non-treated fruits stored in ambient air, increased fruit deterioration (Figure 1). In vitro, vapour studies conducted with $C$. coccodes suppressed the mycelium growth whereas in in vivo studies (wound-inoculated tomatoes), vapours accelerated mycelium growth (as well as tomato cracking) but retarded the shift of fungus from vegetative to reproductive phase [23]. This may imply that the suppression of pathogen development was due, in a large part, to the impact of volatiles on pathogen interactions on fruit tissue with natural volatiles may acted as plant defence elicitor. In previous reports, volatile compounds reduced fruit decay during postharvest treatments in several fresh produce including raspberry, kiwi, strawberry and tomato fruit $[6$, 13,16,19].

\subsection{Effects of Volatiles-Enrichment on Water Loss from Fruit}

The percentage of weight loss was greater (up to 57\%) for ORI-treated fruit during exposure to vapours com-

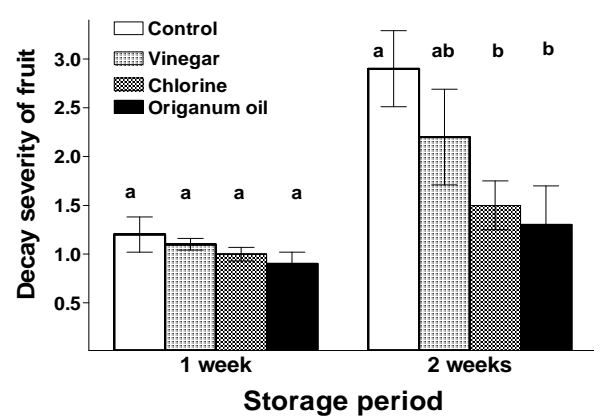

Figure 1. Effects of vinegar $(16 \mathrm{~mL} / \mathrm{L})$, chlorine $(48 \mathrm{~mL} / \mathrm{L} \mathrm{of}$ $5 \% \mathrm{NaOCl})$ or origanum oil $(0.4 \mathrm{~mL} / \mathrm{L})$ vapour on the severity of decay in tomato fruit during (one week) or following (two weeks) exposure to vapour at $12^{\circ} \mathrm{C} / 95 \% \mathrm{RH}$. Scoring (mean value) represents a visual rating of decay severity on fruit using scale of 1 to 5 with 1-clean, no infection, 2-trace, 3-slight, 4-moderate, and 5-severe infection. Values followed by the same letter do not differ significantly $(P<$ 0.05). pared with fruit maintained in ambient air. This effect was not persisted following exposure to ambient air (Table 2). Indeed, fruit weight loss was low for all the treatments (below $2 \%$ ) and with non commercial importance. Previous experiments using eugenol, thymol or menthol vapours revealed benefits due to reduced weight loss in cherries and grapes [8]. Moreover, strawberry and tomato fruit exposed to cinnamon or eucalyptus essential oil vapours [13] or methyl jasmonate (MJ) vapours [19] had not difference in weight loss basis.

\subsection{Effects of Volatiles-Enrichment on Fruit Firmness}

Fruit firmness maintained up to $21 \%(P<0.05)$ in fruit previously exposed to VIN for one week compared with fruits subjected to traditional storage conditions throughout, whereas the effect did not persist following fruit transfer in ambient air (Table 2). ORI- and CHL-enrichment did not affect fruit firmness during or following volatile exposure, being to some extent in accordance with previous studies depending on essential oil source and concentration employed [13]. Fruit firmness on cherries and grapes were unaffected after exposure to eugenol, thymol or menthol vapours $[8,24]$ whereas acetaldehyde vapour-treated avocado delayed fruit softening [10]. Pears (cv. Reld) when treated with emulsions $(3 \%-9 \% \mathrm{v} / \mathrm{v})$ of commercial or refined plant oils at harvest and stored at $0^{\circ} \mathrm{C}$ for 6 months maintained fruit firmness and depended on concentration employed [11]. Several studies highlighted the beneficial effects of natural volatiles, including essential oils and $\mathrm{MJ}$, on fruit firmness by fruit ripening inhibition $[15,19]$ and this is possible the case in the present study, however, a detailed study, in molecular level required, examining the impacts of volatiles in gene and/or protein expression involved in metabolic path- ways i.e. ethylene biosynthetic pathway, which is related to fruit ripening, special for climacteric fruit as tomato.

\subsection{Effects of Enrichment by Volatiles on the Ethylene Production}

Vapour-enrichment resulted in no significant change in the rate of ethylene production during and/or following storage in a volatile-enriched atmosphere (data not presented). However, in the present study, it was not examined the respiration rates and the potential respiration rates changes is needed to be evaluated in details in future.

\subsection{Impacts of Volatiles-Enrichment on the Organic Acid and on Soluble Sugar Composition}

Organic acid content (in terms of percentage of citric 
Table 2. Effects of vinegar $(16 \mathrm{~mL} / \mathrm{L})$, chlorine $(48 \mathrm{~mL} / \mathrm{L}$ of $5 \% \mathrm{NaOCl})$ or origanum oil $(0.4 \mathrm{~mL} / \mathrm{L})$ vapour-enrichment on weight loss $(\%)$, fruit firmness $(\mathrm{N})$ and organic acid content (\% citric acid) in tomato fruit after one week exposure or following transferred to ambient air for an additional one week. Fruit were maintained throughout at $12^{\circ} \mathrm{C}$ and $95 \% \mathrm{RH}$. Values represent the mean of measurements made on six independent fruit per treatment. Values followed by the same letter in each column do not differ significantly $(P<0.05)$.

\begin{tabular}{|c|c|c|c|c|c|c|c|c|c|}
\hline & \multicolumn{3}{|c|}{ Weight loss (\%) } & \multicolumn{2}{|c|}{ Firmness (N) } & \multicolumn{4}{|c|}{ Organic acid content ( $\%$ citric acid) } \\
\hline & 0 & $1 \mathrm{wk}$ & $2 \mathrm{wk}$ & 0 & $1 \mathrm{wk}$ & $2 \mathrm{wk}$ & 0 & $1 \mathrm{wk}$ & $2 \mathrm{wk}$ \\
\hline Control & 0 & $0.21^{\mathrm{b}}$ & $1.48^{\mathrm{a}}$ & 30.7 & $20.7^{\mathrm{b}}$ & $23.5^{\mathrm{ab}}$ & 2.59 & $1.92^{\mathrm{c}}$ & $2.14^{b}$ \\
\hline Vinegar & & $0.23^{\mathrm{ab}}$ & $1.73^{\mathrm{a}}$ & & $26.2^{\mathrm{a}}$ & $21.8^{\mathrm{b}}$ & & $2.45^{\mathrm{a}}$ & $2.73^{\mathrm{a}}$ \\
\hline Chlorine & & $0.43^{\mathrm{ab}}$ & $1.64^{\mathrm{a}}$ & & $22.3^{\mathrm{ab}}$ & $23.0^{\mathrm{ab}}$ & & $2.13^{\mathrm{b}}$ & $2.06^{\mathrm{b}}$ \\
\hline Origan. oil & & $0.51^{\mathrm{a}}$ & $1.85^{\mathrm{a}}$ & & $18.4^{\mathrm{ab}}$ & $26.5^{\mathrm{a}}$ & & $2.10^{\mathrm{abc}}$ & $2.03^{b}$ \\
\hline
\end{tabular}

acid) of VIN- and CHL-treated-fruit increased during vapour exposure or following (only for VIN-treated fruit) storage in ambient air (Table 2), being in accordance with previous reports on cinnamon- or eucalyptus essential oil-treated tomatoes and strawberries [13]. However, fruits exposed to VIN revealed the greatest (up to $22 \%$ ) organic acid content and this may be related to the nature of the natural product and/or the putative interaction between plant tissue and vapours.

Impacts of ORI vapours resulted in increased levels of soluble sugars (fructose and glucose) and total sugars with significant $(P<0.05)$ effects when treated fruit were subsequently transferred in ambient air (Table 3) which may reflect the fruit weight losses. Ju et al. [11] reported that total soluble solids (TSS) and TA of pears treated with emulsions of plant oils, were maintained and depended on the concentration employed. Vapours of essential oil (cinnamon and eucalyptus) applied on tomatoes and strawberries increased TSS. However, this effect did not persist following transfer in ambient air, with the exception of "cherry" tomatoes [13]. Moreover, MJ- and tea tree oil-treated raspberries maintained higher levels of sugars and organic acids compared to untreated fruit [6]. Similarly MJ-treated papaya retained higher organic acids than the control fruit [15]. In contrast, basil oil spray emulsion $(0.16 \% \mathrm{v} / \mathrm{v})$ treatment affected the texture and the flavour of the banana fruit but did not have any significant effect on TSS alter induced ripening [12]. However, in the present study, preliminary observations on organoleptic characteristics revealed no changes in fruit colour (discoloration) or aroma after volatiles treatments (data not presented).

\subsection{Effects of Volatiles-Enrichment on Ascorbic Acid (Vitamin C) and Phenolic Content}

Ascorbic acid content in tomato fruit was not differentiated (with the exception of vinegar treatment) during exposure, but tended to increase throughout fruit storage following transfer in ambient air (Table 4). The effect was significant $(P<0.05)$ for all the treatments with origanum oil marked the greatest value (up to $62 \%$ comparing to the control). Vitamin C (ascorbic and L-dehydroascorbic acid) has a high antioxidant power, providing protection against the presence of free radicals and consequently participating in the prevention of many degenerative diseases as well as it is an essential nutrient for human.

Vapour-treatments of VIN and CHL decreased $(P<$ $0.05)$ phenolics of fruit during vapour exposure and this effect persisted only for VIN-treated fruit following exposure and transfer in ambient air (Table 4). An increased phenolic content, but not significant differ from control, revealed for ORI-treated fruit. A similar pattern observed in essential oil-treated tomato and strawberry fruit [13]. It's worthwhile to point that most of the antimicrobial activity in essential oils from spices and culinary herbs appears to be associated with interactions between phenolic compounds and the food matrix [25].

\subsection{Effects of Volatiles-Enrichment on Carotenoids Composition}

VIN and CHL increased lycopene concentration during exposure to vapours and this effect persisted only for VIN following exposure and transfer in ambient air (Figure 2) possible providing increased antioxidative status to some extent. However, the mechanism of this stimulation is not clear and further research required. Application of chlorine, in general, reduced the carotenoids concentration following exposure of vapours and transfer in ambient air. However, ORI-treated fruit revealed no differences on carotenoids concentration $(\beta$ carotene, lutein and lycopene) during exposure but lycopene increased following transfer in ambient air (Figure 2).

Antioxidants prevent the accumulation of potentially damaging reactive oxygen species (ROS), which occur as 
Table 3. Effects of vinegar $(16 \mathrm{~mL} / \mathrm{L})$, chlorine $(48 \mathrm{~mL} / \mathrm{L}$ of $5 \% \mathrm{NaOCl})$ or origanum oil $(0.4 \mathrm{~mL} / \mathrm{L})$ vapour-enrichment on glucose, fructose and total sugars concentration in tomato fruit after one week exposure or following transferred to ambient air for an additional one week. Fruit were maintained throughout at $12^{\circ} \mathrm{C}$ and $95 \% \mathrm{RH}$. Values represent the mean of measurements made on six independent fruit per treatment. Values followed by the same letter in each column do not differ significantly $(P<0.05)$.

\begin{tabular}{lccccccccc}
\hline & \multicolumn{3}{c}{ Glucose (mmol/g f.wt) } & \multicolumn{3}{c}{ Fructose (mmol/g f.wt) } & \multicolumn{3}{c}{ Total sugars (mmol/g f.wt) } \\
\cline { 2 - 10 } & 0 & $1 \mathrm{wk}$ & $2 \mathrm{wk}$ & 0 & $1 \mathrm{wk}$ & $2 \mathrm{wk}$ & 0 & $1 \mathrm{wk}$ & $2 \mathrm{wk}$ \\
\hline Control & 0.204 & $0.316^{\mathrm{a}}$ & $0.156^{\mathrm{b}}$ & 0.137 & $0.221^{\mathrm{a}}$ & $0.109^{\mathrm{b}}$ & 0.348 & $0.541^{\mathrm{a}}$ & $0.295^{\mathrm{b}}$ \\
Vinegar & & $0.199^{\mathrm{b}}$ & $0.198^{\mathrm{b}}$ & & $0.139^{\mathrm{b}}$ & $0.139^{\mathrm{b}}$ & $0.344^{\mathrm{b}}$ & $0.345^{\mathrm{b}}$ \\
Chlorine & & $0.249^{\mathrm{ab}}$ & $0.224^{\mathrm{b}}$ & & $0.176^{\mathrm{ab}}$ & $0.159^{\mathrm{b}}$ & $0.431^{\mathrm{ab}}$ & $0.389^{\mathrm{b}}$ \\
Origan. oil & & $0.208^{\mathrm{ab}}$ & $0.416^{\mathrm{a}}$ & & $0.142^{\mathrm{ab}}$ & $0.279^{\mathrm{a}}$ & & $0.357^{\mathrm{ab}}$ & $0.707^{\mathrm{a}}$ \\
\hline
\end{tabular}

Table 4. Effects of vinegar $(16 \mathrm{~mL} / \mathrm{L})$, chlorine $(48 \mathrm{~mL} / \mathrm{L}$ of $5 \% \mathrm{NaOCl})$ or origanum oil $(0.4 \mathrm{~mL} / \mathrm{L})$ vapour-enrichment on ascorbic acid and total phenolic content in tomato fruit after one week exposure or following transferred to ambient air for an additional one week. Fruit were maintained throughout at $12^{\circ} \mathrm{C}$ and $95 \% \mathrm{RH}$. Values represent the mean of measurements made on six independent fruit per treatment. Values followed by the same letter in each column do not differ significantly $(P<0.05)$.

\begin{tabular}{ccccccc}
\hline & \multicolumn{3}{c}{$\begin{array}{c}\text { Ascorbic acid } \\
(\mathrm{mg} / \mathrm{g} \mathrm{f} \cdot \mathrm{wt} .)\end{array}$} & \multicolumn{3}{c}{$\begin{array}{c}\text { Total Phenolics } \\
(\mathrm{GAE} \mu \mathrm{mol} / \mathrm{g} \mathrm{f} \cdot \mathrm{wt} .)\end{array}$} \\
\cline { 2 - 7 } & 0 & $1 \mathrm{wk}$ & $2 \mathrm{wk}$ & 0 & $1 \mathrm{wk}$ & $2 \mathrm{wk}$ \\
\hline Control & 0.087 & $0.077^{\mathrm{a}}$ & $0.060^{\mathrm{c}}$ & 2.065 & $2.117^{\mathrm{a}}$ & $1.831^{\mathrm{ab}}$ \\
Vinegar & & $0.051^{\mathrm{b}}$ & $0.076^{\mathrm{b}}$ & & $1.462^{\mathrm{b}}$ & $1.960^{\mathrm{ab}}$ \\
Chlorine & $0.064^{\mathrm{a}}$ & $0.075^{\mathrm{b}}$ & & $1.353^{\mathrm{b}}$ & $1.664^{\mathrm{b}}$ \\
Origan.oil & & $0.062^{\mathrm{a}}$ & $0.159^{\mathrm{a}}$ & & $2.306^{\mathrm{a}}$ & $2.125^{\mathrm{a}}$ \\
\hline
\end{tabular}

a product of cellular metabolism and act as secondary messengers in hormone signal transduction [26]. Impacts of storage treatments on the antioxidative properties and products of tomato are of concern because tomato fruit is recognized to be particularly rich in several antioxidants such as Vitamin C, carotenoids (especially lycopene), Vitamin A plus some flavonoids and other phenolic compounds, and it protects the human body tissue against oxidative attacks $[27,28]$. It has long been recognized that naturally occurring substances in higher plants have antioxidant activity. Interestingly, volatile-treatment resulted in significant change in some compounds with known antioxidant activity (ascorbic acid and carotenoids concentration) exhibited by tomato fruit. Phenolic compounds are plant secondary metabolites, contribute substantially to the antioxidant complement of many fruit species, by playing an important role in inhibiting reactions mediated by reactive oxygen species, which are associated with a number of human diseases [29] having potential health effects [30] and preventing of chronic

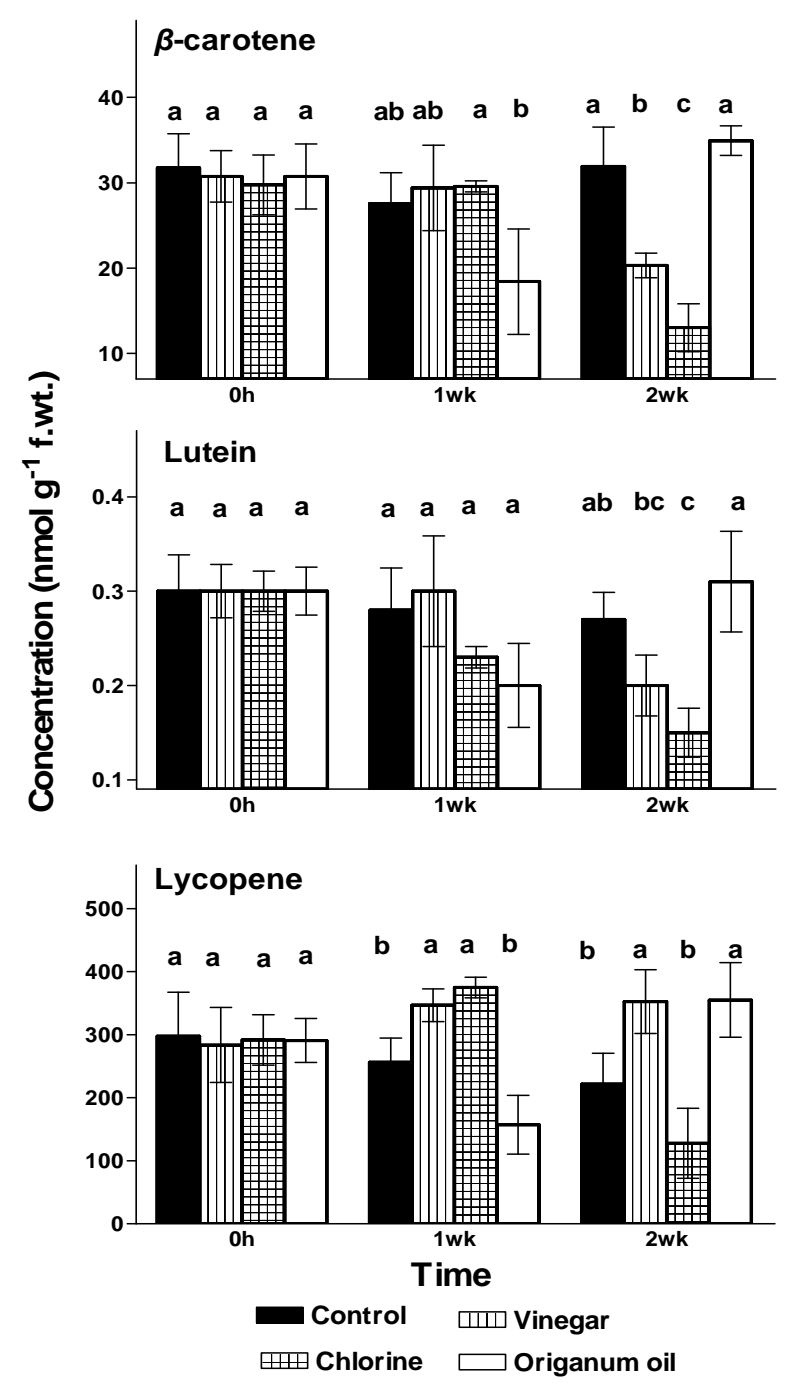

Figure 2. Effects of vinegar $(16 \mathrm{~mL} / \mathrm{L})$, chlorine $(48 \mathrm{~mL} / \mathrm{L}$ of $5 \% \mathrm{NaOCl})$ or origanum oil $(0.4 \mathrm{~mL} / \mathrm{L})$ vapour on the $\beta$-carotene, lutein and lycopene concentration (nmol/g f.wt.) in tomato fruit during (one week) or following (two weeks) exposure to vapour at $12^{\circ} \mathrm{C} / 95 \% \mathrm{RH}$. Mean values followed by the same letter do not differ significantly $(P<0.05)$. 
diseases such as cardiovascular disease and cancer [31]. Moreover, phenols played important role in both sensory and nutritional quality of fruits and vegetables [32]. Previous studies suggested that the increase of the phenolic compounds resulted in the increase of the antioxidant activity in sweet basil by MJ treatment, which in consequence stimulated plant defence mechanisms [33]. In this regard, it is worth noting the marked stimulation in ascorbic acid and lycopene concentration for volatile-treated fruit that might increased the phenolic content, as marked for origanum-treated fruit.

At the market interface, only produce that corresponds to the expectations of the consumer is acceptable. Thus, it is vital to assess the effects of potentially innovative practices on sensory and organoleptic properties of fruit and vegetables. Fruit firmness is an important quality attribute and is directly related to enhance the storability potential and to induce greater resistance to decay and mechanical damage [34]. It is known that cell wall matrices, especially pectins, undergo disruption during fruit ripening as a consequence fruit softening that accompanies ripening [35].

Natural volatiles are known to be effective against a wide spectrum of microorganisms and leave no detectable residues and may improve fruit quality and presservation of fresh produce. Thus, the potential for using natural volatiles for maintenance fruit quality in storage and/or transit was introduced by the present study. Consequently, these findings may have considerable commercial significance, but first efficacy must confirmed employing microbial studies (both in vitro and in vivo) and in a commercial context where produce is submitted to vapour-enrichment in the usual storage/transit bins, cartons or boxes, including coating fruit with plant volatiles and/or modified atmosphere packaging on a wider range of fresh produce. Natural volatiles are not as broad spectrum as synthetic pesticides, but their effectiveness can be improved by using them in conjunction with carefully designed packaging. Considerable care is needed in application of the natural volatiles as continuous fumigant effect may result in tainting of the product as thin skinned products are more prone to tainting than those with thicker skins. Essential oils which have been registered as Food Additives are much easier to register for postharvest use than new synthetic pesticides. Application of these oils via the vapour phase should also make their use more cost effective than dipping. We are continuing our work in an effort to determine the optimum concentration of oil for maximum control of the pathogens with acceptable levels of tainting of the product.

\section{Conclusions}

This study demonstrated that natural volatiles may main- tain fruit quality in addition to the well documented antimicrobial protection during fresh produce storage and transit. Origanum oil-treated fruit increased sugar content during exposure and increased lycopene and ascorbic acid following exposure and transfer in ambient air. Vinegar-enrichment maintained fruit firmness, acidity and increased lycopene concentration (including chlorine treatment) during exposure, though the effect was sustained only for acidity following storage in ambient air. Total phenolics declined during vinegar and chlorine exposure but tended to increase following transfer in ambient air. Further investigation is needed before commercial application in order to optimize concentration and time for both antimicrobial and quality aspects.

\section{Acknowledgements}

This study was supported by the National Research Foundation of Greece (IKY) via the award of a Post-Doc scholarship to NT. We thank Dr. Paul Donohoe and colleagues, Environmental Mass Spectrometry Unit, Newcastle University, UK, for their respective technical inputs on oil analysis.

\section{REFERENCES}

[1] N. S. Alzoreky and K. Nakahara, "Antimicrobial Activity of Extracts from Some Edible Plants Commonly Consumed in Asia," International Journal of Food Microbiology, Vol. 80, No. 3, 2003, pp. 223-230. doi:10.1016/S0168-1605(02)00169-1

[2] K. M. Soliman and R. I. Badeaa, "Effect of Oil Extracted from Some Medicinal Plants on Different Mycotoxigenic Fungi," Food and Chemical Toxicology, Vol. 40, No. 11, 2002, pp. 1669-1675. doi:10.1016/S0278-6915(02)00120-5

[3] M. Valero and M. C. Salmeron, "Antibacterial Activity of 11 Essential Oils against Bacillus Cereus in Tyndallized Carrot Broth," International Journal of Food Microbiology, Vol. 85, No. 1-2, 2003, pp. 73-81. doi:10.1016/S0168-1605(02)00484-1

[4] A. Prakash and J. Rao, "Botanical Pesticides in Agriculture," CRC Press, Boca Raton, 1997, p. 461.

[5] P. Sholberg, P. Haag, R. Hocking and K. Bedford, "The Use of Vinegar Vapor to Reduce Postharvest Decay of Harvested Fruit," HortScience, Vol. 35, No. 5, 2000, pp. 898-903.

[6] C. Y. Wang, "Maintaining Postharvest Quality of Raspberries with Natural Volatile Compounds," International Journal of Food Science and Technology, Vol. 38, No. 8, 2003, pp. 869-875. doi:10.1046/j.0950-5423.2003.00758.x

[7] W. T. Liu, C. L. Chu and T. Zhou, "Thymol and Acetic Acid Vapors Reduce Postharvest Brown Rot of Apricots and Plums," HortScience, Vol. 37, No. 1, 2002, pp. 151156.

[8] M. Serrano, D. Martinez-Romero, S. Castillo, F. Guillen 
and D. Valero, "The Use of the Natural Antifungal Compounds Improves the Beneficial Effect of MAP in Sweet Cherry Storage," Innovative Food Science and Emerging Technologies, Vol. 6, No. 1, 2005, pp. 115-123. doi:10.1016/j.ifset.2004.09.001

[9] C. C. Thanassopoulos and Y. Laidou, "On the Biological Control of Botrytis cinerea on Kiwifruit cv 'Hayward' during Storage," Acta Horticulturae, Vol. 444, No. 2, 1997, pp. 757-762.

[10] E. Pesis, D. Faiman and S. Dori, "Postharvest Effects of Acetaldehyde Vapour on Ripening-Related Enzyme Activity in Avocado Fruit," Postharvest Biology and Technology, Vol. 13, No. 3, 1998, pp. 245-253. doi:10.1016/S0925-5214(98)00008-8

[11] Z. Ju, Y. Duan and Z. Ju, "Plant Oil Emulsion Modifies Internal Atmosphere, Delays Fruit Ripening, and Inhibits Internal Browning in Chinese Pears," Postharvest Biology and Technology, Vol. 20, No. 3, 2000, pp. 243-250. doi:10.1016/S0925-5214(00)00120-4

[12] S. Anthony, K. Abeywickrama and S. W. Wijeratnam, "The Effect of Spraying Essential Oils Cymbopogon nardus, Cymbopogon flexuosus and Ocimum basilicum on Postharvest Diseases and Storage Life of Embul Banana," Journal of Horticultural Science and Biotechnology, Vol. 78, No. 6, 2003, pp. 780-785.

[13] N. G. Tzortzakis, "Maintaining Postharvest Quality of Fresh Produce with Volatile Compounds," Innovative Food Science and Emerging Technologies, Vol. 8, No. 1, 2007, pp. 111-116. doi:10.1016/j.ifset.2006.08.001

[14] D. A. Brummell and M. H. Harpster, "Cell Wall Metabolism in Fruit Softening and Quality and Its Manipulation in Transgenic Plants," Plant Molecular Biology, Vol. 47, No. 1-2, 2001, pp. 311-340. doi:10.1023/A:1010656104304

[15] G. A. Gonzalez-Aguilar, J. G. Buta and C. Y. Wang, "Methyl Jasmonate and Modified Atmosphere Packaging (MAP) Reduce Decay and Maintain Postharvest Quality of Papaya 'Sunrise'," Postharvest Biology and Technology, Vol. 28, No. 3, 2003, pp. 361-370.

[16] C. Y. Wang and J. G. Buta, "Maintaining Quality of Fresh-Cut Kiwifruit with Volatile Compounds," Postharvest Biology and Technology, Vol. 28, No. 1, 2003, pp. 181-186. doi:10.1016/S0925-5214(02)00125-4

[17] J. C. Beaulieu, G. Peiser and M. E. Saltveit, "Acetaldehyde is a Causal Agent Responsible for Ethanol-Induced Ripening Inhibition in Tomato Fruit," Plant Physiology, Vol. 113, No. 2, 1997, pp. 431-439.

[18] A. Yanuriati, G. P. Savage and R. N. Rowe, "The Effects of Ethanol Treatment on the Metabolism, Shelf Life and Quality of Stored Tomatoes at Different Maturities and Temperatures," Journal of the Science of Food and Agriculture, Vol. 79, No. 7, 1999, pp. 995-1002. doi:10.1002/(SICI)1097-0010(19990515)79:7<995::AIDJSFA315>3.0.CO;2-D

[19] N. G. Tzortzakis and C. D. Economakis, "Maintaining Postharvest Quality of Tomato Fruit Employing Methyl Jasmonate and Ethanol Vapour Treatment," Journal of Food Quality, Vol. 30, No. 5, 2007, pp. 567-580. doi:10.1111/j.1745-4557.2007.00143.x

[20] F. Mencarelli and P. Savarese, "Ripening of Kiwifruit Exposed to Ethanol and Acetaldehyde Vapours," Horticultural Science, Vol. 26, No. 5, 1991, pp. 566-569.

[21] N. G. Tzortzakis, A. Borland, I. Singleton and J. D. Barnes, "Impact of Atmospheric Ozone-Enrichment on Quality-Related Attributes of Tomato Fruit," Postharvest Biology and Technology, Vol. 45, No. 3, 2007, pp. 317326. doi:10.1016/j.postharvbio.2007.03.004

[22] K. Helrich, Ed., "AOAC Official Methods of Analysis. Vitamin C (Ascorbic Acid)," 15th Edition, Association of Official Analytical Chemists, Gaithersburg, Vol. 2, 1990, pp. 1058-1059.

[23] N. G. Tzortzakis, "Ethanol, Vinegar and Origanum vulgare Oil Vapour Suppress the Development of Anthracnose Rot in Tomato Fruit," International Journal of Food Microbiology, Vol. 142, No. 1-2, 2010, pp. 14-18. doi:10.1016/i.ijfoodmicro.2010.05.005

[24] D. Martinez-Romero, S. Castillo, J. M. Valverde, F. Guillen, D. Valero and M. Serrano, "The Use of Natural Aromatic Essential Oils Helps to Maintain Postharvest Quality of 'Crimson' Table Grapes," Acta Horticulturae, Vol. 682, 2005, pp. 1723-1729.

[25] G. E. Nuchas and C. C. Tassou, "Traditional Preservatives-Oils and Spices," In: R. K. Robinson, C. A. Batt and P. D. Patel, Eds., Encyclopedia of Food Microbiology, Academic Press, London, 2000, pp. 1717-1722.

[26] P. K. Andrews, D. A. Fahy and C. H. Foyer, "Relationship between Fruit Exocarp Antioxidants in the Tomato (Lycopersicon esculentum) High Pigment-1 Mutant during Development," Physiologia Plantarum, Vol. 120 , No. 4, 2004, pp. 519-528. doi:10.1111/j.0031-9317.2004.0279.x

[27] A. A. Abushita, A. Hebshi, H. G. Daood and P. A. Biacs, "Determination of Antioxidant Vitamins in Tomatoes," Food Chemistry, Vol. 60, No. 2, 1997, pp. 207-212. doi:10.1016/S0308-8146(96)00321-4

[28] L. Scalfi, V. Fogliano, A. Pentangelo, G. Graziani, I. Giordano and A. Ritieni, "Antioxidant Activity and General Fruit Characteristics in Different Ecotypes of Corbarini Small Tomatoes," Journal of Agricultural and Food Chemistry, Vol. 48, No. 4, 2000, pp. 1363-1366. doi:10.1021/jf990883h

[29] S. E. S. N. Karakaya and A. A. Tas, "Antioxidant Activity of Some Foods Containing Phenolic Compounds," International Journal of Food Sciences and Nutrition, Vol. 52, No. 6, 2001, pp. 501-508. doi:10.1080/713671810

[30] I. M. Heinonen, A. S. Meyer and E. N. Frankel, "Antioxidant Activity of Berry Phenolics on Human Low Density Lipoprotein and Liposome Oxidation," Journal of Agricultural and Food Chemistry, Vol. 46, No. 10, 1998, pp. 4107-4112. doi:10.1021/jf980181c

[31] Y. Arai, S. Watanabe, M. Kimira, K. Shimoi, R. Mochizuki and N. Kinae, "Dietary Intakes of Flavonols, Flavones and Isoflavones by Japanese Women and the Inverse Correlation between Quercetin Intake and Plasma LDL Cholesterol," Journal of Nutrition, Vol. 130, No. 9, 
2000, pp. 2378-2383.

[32] F. A. Tomas-Barberan and J. C. Espin, "Phenolic Compounds and Related Enzymes as Determinants of Quality in Fruits and Vegetables," Journal of Science and Food Agriculture, Vol. 81, No. 9, 2001, pp. 853-876. doi:10.1002/jsfa. 885

[33] H. J. Kim, F. Chen, X. Wang and N. C. Rajapakse, "Effect of Methyl Jasmonate on Secondary Metabolites of Sweet Basil (Ocimum basilicum L.)," Journal of Agricultural and Food Chemistry, Vol. 54, No. 6, 2006, pp. 2327-2332. doi:10.1021/jf051979g
[34] D. M. Barret and C. Gonzalez, "Activity of Softening Enzymes during Cherry Maturation," Journal of Food Science, Vol. 59, No. 3, 1994, pp. 574-577. doi:10.1111/j.1365-2621.1994.tb05565.x

[35] G. A. Tucker and D. Greison, "Fruit Ripening," In: D. D. Davies, Ed., The Biochemistry of Plants, Physiology of Metabolism, Academic Press, New York, Vol. 12, 1987, pp. 265-318. 